\title{
Pengembangan dan Evaluasi Aplikasi e-RT di Kelurahan Periuk Kecamatan Periuk Kota Tangerang
}

\author{
${ }^{1}$ Seng Hansun, ${ }^{2}$ Muh. Salehuddin, dan ${ }^{1}$ Marcel Bonar Kristanda

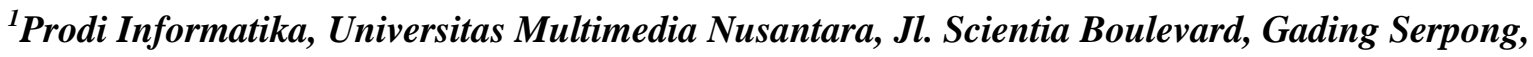 \\ Tangerang, Banten-15811 \\ ${ }^{2}$ Prodi Teknik Fisika, Universitas Multimedia Nusantara, Jl. Scientia Boulevard, Gading Serpong, \\ Tangerang, Banten-15811
}

E-mail: seng.hansun@ lecturer.umn.ac.id

\begin{abstract}
Abstrak - Peran Rukun Tetangga (RT) sebagai unit kemasyarakatan terkecil sangatlah penting dalam menjaga dan melestarikan nilai kehidupan masyarakat. Namun demikian, dalam penyelenggaraan pelayanan di tingkat RT kerap ditemukan berbagai permasalahan, seperti lamanya proses pelayanan, kurangnya sosialisasi program Pemda dan RT setempat, dan kurangnya fasilitas pendukung kinerja pengurus. Salah satu solusi untuk menjawab permasalahan yang ada adalah dengan membuat aplikasi e-RT yang harapannya dapat mendukung kinerja pelayanan $R T$ dan menjadi sarana sosialisasi berbagai program yang ada. Kegiatan Pengabdian kepada Masyarakat (PKM) ini diusulkan dan dilaksanakan dalam jangka waktu delapan bulan. Kegiatan ini mendapatkan dukungan positif warga masyarakat sebagai mitra kegiatan PKM, utamanya pengurus RT 06 di Kelurahan Periuk, Kecamatan Periuk, Kota Tangerang. Hasil akhir kegiatan PKM berupa sebuah aplikasi e-RT yang dapat diakses dengan mudah oleh seluruh warga RT. Pada artikel ini, evaluasi aplikasi e-RT yang telah dikembangkan dipaparkan dengan mengacu pada instrumen WEBQUAL 4.0 dan mencapai hasil 80,29\%.
\end{abstract}

Kata Kunci-e-RT, Kelurahan Periuk, Evaluasi, WEBQUAL 4.0

\begin{abstract}
Rukun Tetangga (RT) role as the smallest unit in the hierarchical structure of Regional Government is very important in guarding and preserving the norm and values of Indonesian people. However, in the management and services delivery at RT level various problems could be happened, such as the long services delivery time, lack of Government and local RT program socialization, and lack of the committee members support facility. A solution offered to solve these problems is by creating e-RT application that can support the services performance of $R T$ officer as well as a means to distribute various Government and RT programs. The Community Service Program (PKM) was then be proposed and implemented with an eight months-time planning. This program got a positive support, both from the UMN Research and Community Service Institution (LPPM UMN) and the community that become the partner for this program, i.e., RT 06 in Periuk village, Periuk subdistrict, Tangerang City. The final result of this program is an e-RT application based on mobile web app, which can be easily accessed by all community members. In this article, the application evaluation is described by referring the WEBQUAL 4.0 instrument with $80.29 \%$ result.
\end{abstract}

Keywords - e-RT, Periuk subdistrict, evaluation, WEBQUAL 4.0

\section{Pendahuluan}

Rukun Tetangga (RT) sebagaimana yang didefinisikan dalam Peraturan Daerah Kota Tangerang adalah "lembaga kemasyarakatan yang dibentuk melalui musyawarah masyarakat dalam rangka membantu Lurah dalam penyelenggaraan pelayanan pemerintahan, pembangunan, dan kemasyarakatan di kelurahan" [1]. RT berperan dalam meningkatkan kelancaran tugas pemerintahan, pembangunan, dan kemasyarakatan di tingkat desa hingga kelurahan [2]. Oleh karenanya, meskipun merupakan unit lembaga kemasyarakatan terkecil [3], RT memiliki peran yang sangat penting dalam menjaga dan melestarikan nilai kehidupan masyarakat dan bangsa Indonesia.
Badan Pusat Statistik Kota Tangerang [4] dalam situs resminya mendata jumlah RT yang cukup besar di Kota Tangerang, seperti yang terlihat pada Tabel 1. Hal ini memperlihatkan banyaknya jumlah penduduk Kota Tangerang, sehingga pelaksanaan tugas dan fungsi RT sangatlah penting dalam menjaga kerukunan dan ketentraman lingkungan serta memastikan pembangunan daerah berjalan dengan lancar.

Tabel 1 Statistik BPS Kota Tangerang Tahun 2015 [4]

\begin{tabular}{lccc}
\hline \multirow{2}{*}{ Kecamatan } & \multicolumn{3}{c}{ Jumlah } \\
\cline { 2 - 4 } & Kelurahan & RW & RT \\
\hline Karangtengah & 7 & 74 & 361 \\
Cipondoh & 10 & 100 & 612 \\
Pinang & 11 & 77 & 464 \\
Tangerang & 8 & 79 & 404 \\
\hline
\end{tabular}




\begin{tabular}{lccc}
\hline Karawaci & 16 & 127 & 534 \\
Jatiuwung & 6 & 41 & 225 \\
Cibodas & 6 & 90 & 471 \\
Periuk & 5 & 71 & 435 \\
Batuceper & 7 & 47 & 231 \\
Neglasari & 7 & 49 & 239 \\
Benda & 5 & 41 & 199 \\
Ciledug & 8 & 104 & 399 \\
Larangan & 8 & 90 & 426 \\
Total & $\mathbf{1 0 4}$ & $\mathbf{9 9 0}$ & $\mathbf{5 . 0 0 0}$ \\
\hline
\end{tabular}

Dalam pelaksanaan tugas dan fungsinya, tidak jarang ditemukan berbagai permasalahan di tingkat RT, baik yang muncul dari internal pengurus RT sendiri maupun dari eksternal pengurus RT. Pelayanan yang masih manual dan membutuhkan tenaga serta waktu yang lama, kurang tersosialisasinya program Pemerintah Daerah maupun program RT setempat, serta kurangnya fasilitas pendukung kinerja, merupakan contoh dari berbagai permasalahan yang kerap terjadi. Untuk itu, dalam kegiatan Pengabdian kepada Masyarakat (PKM) Universitas Multimedia Nusantara (UMN) diajukan solusi untuk mengatasi berbagai permasalahan dalam proses pelayanan RT tersebut, yakni berupa aplikasi e-RT.

Mitra utama dalam kegiatan PKM adalah RT 06 Kelurahan Periuk, Kecamatan Periuk, Kota Tangerang yang terletak di Klaster Perumahan Global Mansion dan berjarak sekitar $18 \mathrm{~km}$ dari Universitas Multimedia Nusantara selaku perguruan tinggi pengusul Program PKM ini.

Adapun penelitian serupa terkait permasalahan yang sering dijumpai di tingkat RT, dapat dilihat pada publikasi Eeda [5], Layuk [6], dan Hamidah [7]. Beberapa contoh solusi yang ditawarkan guna menjawab permasalahan di tingkat RT juga telah disajikan dalam publikasi Mulyawan, dkk. [8] yang mengembangkan sistem informasi administrasi kependudukan RT/RW, dan Nasrudin [9] terkait pemanfaatan SMS Gateway sebagai media perantara staf RW dan warga.

Solusi yang diajukan serta menjadi luaran utama kegiatan PKM ini adalah pembuatan aplikasi e-RT di RT 06 Kelurahan Periuk. Aplikasi e-RT yang telah diterapkan selanjutnya dievaluasi dengan menggunakan instrument WEBQUAL 4.0 yang menjadi fokus utama pembahasan dalam publikasi karya ilmiah ini.

\section{METODE}

Metode serta tahapan penyelenggaraan kegiatan PKM disajikan pada Gambar 1 yang dapat dijabarkan secara singkat sebagai berikut.

1. Survei awal

Survei dilakukan dengan teknik wawancara kepada Ketua RT 06 Kelurahan Periuk guna mengetahui kondisi dan gambaran permasalahan yang dihadapi oleh mitra PKM.

2. Identifikasi Permasalahan Mitra

Tim pengusul Program PKM melakukan identifikasi permasalahan mitra yang kemudian didiskusikan bersama dengan Ketua dan Pengurus RT 06.

3. Penentuan Prioritas dan Solusi Permasalahan Tim pengusul Program PKM bersama dengan Ketua dan Pengurus RT 06 menentukan lima (5) prioritas permasalahan utama yang diangkat dan solusi yang ditawarkan.

4. Perancangan dan Pembangunan Aplikasi e-RT Perancangan dimulai dengan desain alur berupa diagram alir, database schema, serta desain antarmuka aplikasi. Selanjutnya dengan mengikuti model waterfall, tahap pembangunan aplikasi dilaksanakan.

5. Penerapan dan Pelatihan Aplikasi e-RT Tahap berikutnya adalah penerapan aplikasi eRT yang disertai dengan sosialisasi dan pelatihan aplikasi e-RT bagi warga dan pengurus RT 06. Setelah penerapan dan sosialisasi, evaluasi aplikasi e-RT yang diterapkan juga dilaksanakan oleh tim Pengusul.

6. Dokumentasi dan Publikasi

Di tahap akhir, dokumentasi dan publikasi kegiatan PKM dilaksanakan dalam bentuk laporan akhir Program PKM serta luaran publikasi ilmiah di konferensi maupun jurnal tingkat nasional. 
Jati Emas (Jurnal Aplikasi Teknik dan Pengabdian Masyarakat) Vol. 5 No. 1 Maret 2021 - e. ISSN: 2550-0821

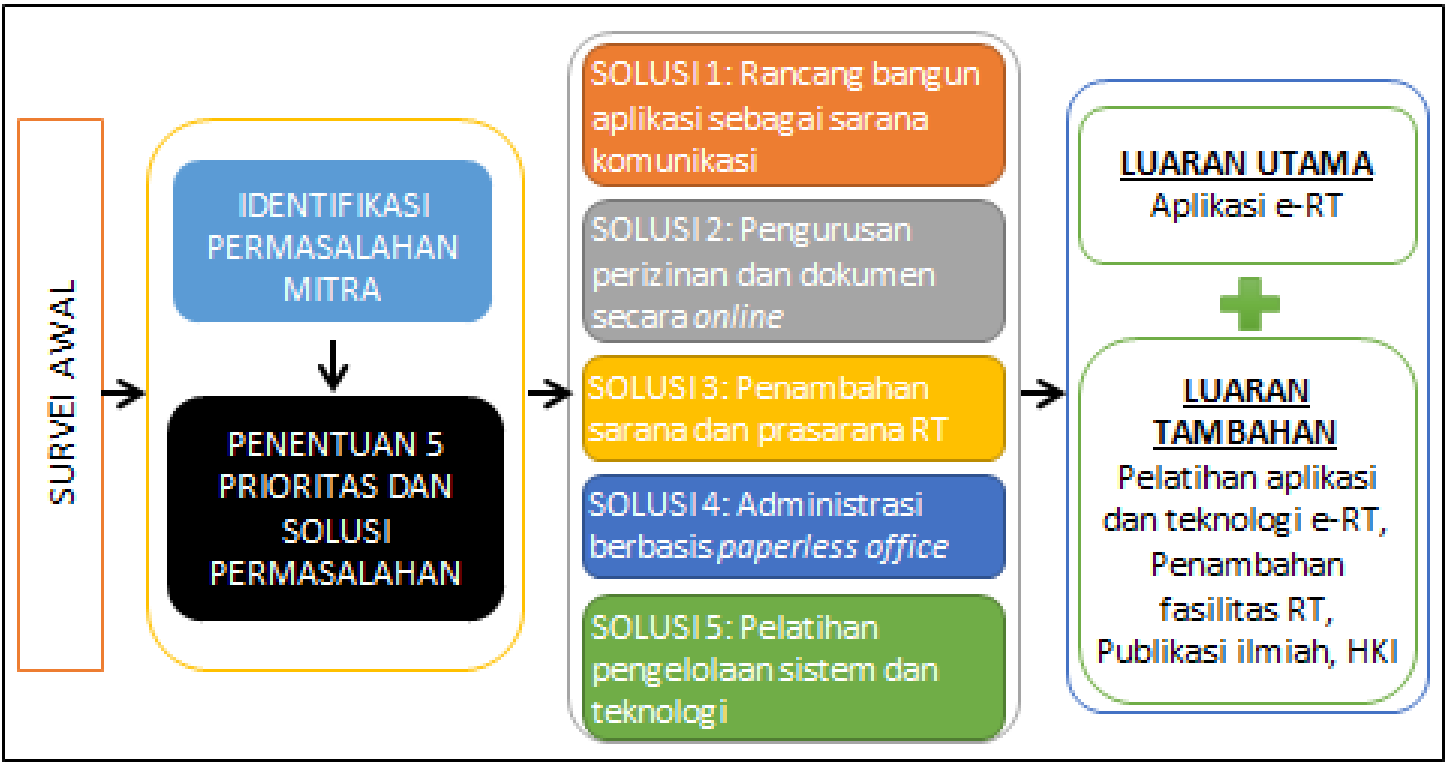

Gambar 1. Metode dan Tahapan Pelaksanaan PKM [10]

\section{HASIL PELAKSANAAN}

Selama pengembangan program Pengabdian kepada Masyarakat (PKM) ini dilakukan terdapat beberapa perubahan dan tantangan yang terjadi. Perubahan dan tantangan utama yang paling dirasakan berdampak terhadap program PKM ini adalah terjadinya pergantian pengurus RT dan RW di Kelurahan Periuk Kota Tangerang. Pergantian pengurus ini menyebabkan terjadinya perubahan beberapa solusi dan target luaran program PKM, namun tanpa melupakan tujuan PKM, yakni membangun suatu aplikasi e-RT telah dicapai dan dipublikasikan secara daring melalui tautan http://ertglobalmansion.com/

Aplikasi e-RT memiliki beberapa menu dengan fiturnya masing-masing, sebagai berikut:

- Beranda: menyajikan laman awal aplikasi e-RT dan berisi komentar singkat warga, serta sedikit deskripsi tentang aplikasi e-RT

- Tentang: berisikan informasi tentang RT 06 sebagai mitra PKM serta pengurusnya saat ini

- Layanan: berisikan informasi dan layanan umum yang bisa diakses oleh seluruh warga RT 06

- Galeri: berisikan photo-photo kegiatan warga RT 06 yang dapat diperbesar dan diunduh

- Fasilitas: berisikan photo-photo fasilitas yang ada di RT 06 yang dapat diperbesar dan diunduh

- Berita: berisikan berita dan pengumuman yang dapat diakses oleh warga RT 06

- Unduhan: berisikan formulir dan dokumen yang dapat diunduh oleh warga RT 06

- Kontak: berisikan informasi nomor-nomor penting yang dapat digunakan oleh warga RT 06

Selain beberapa fitur di atas, aplikasi e-RT juga dilengkapi dengan bagian back-end system yang dapat digunakan oleh administrator yang ditunjuk oleh Pengurus RT untuk mengelola isi aplikasi e-RT yang telah dikembangkan. Berikut disajikan beberapa tangkapan layar dari aplikasi e-RT yang berhasil dibangun.

Gambar 2 memperlihatkan halaman Beranda aplikasi e-RT yang telah dibangun. Selain berisikan informasi umum terkait e-RT, halaman ini memuat komentar warga dan pengurus RT tentang aplikasi e-RT, dan informasi pengembang aplikasi eRT sebagai bagian dari program PKM yang dilaksanakan.

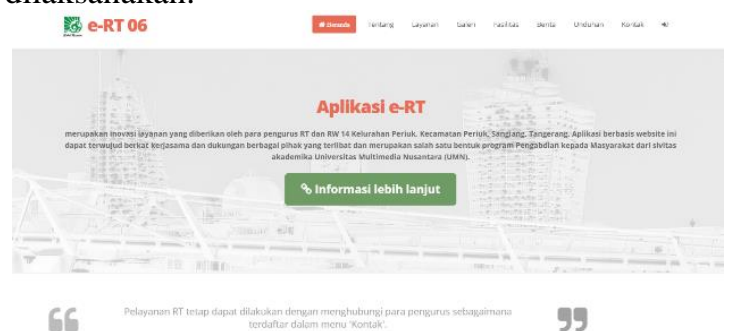

Komentar warga dan pengurus RT tentang situs ini
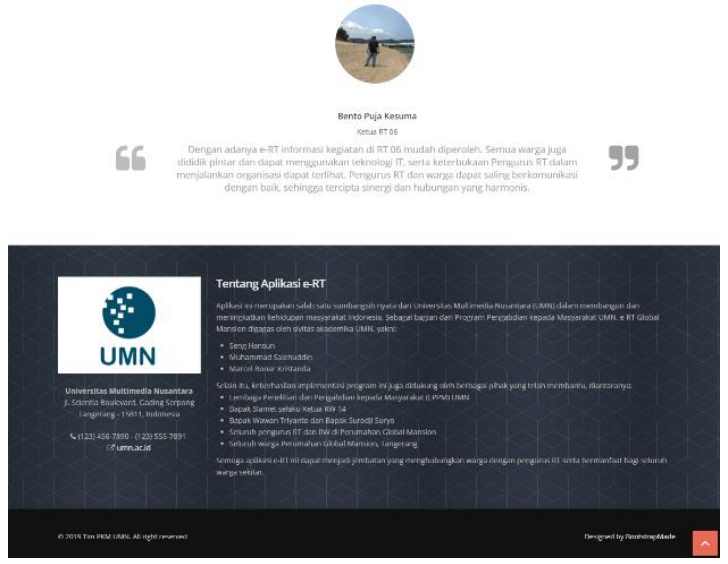

Gambar 2. Halaman Beranda e-RT 
Gambar 3 menyajikan halaman Tentang RT 06 di Kelurahan Periuk Kota Tangerang. Melalui halaman ini warga sekitar maupun khalayak umum dapat mengetahui informasi singkat terkait RT 06 dan para pengurus RT 06 yang aktif saat ini.
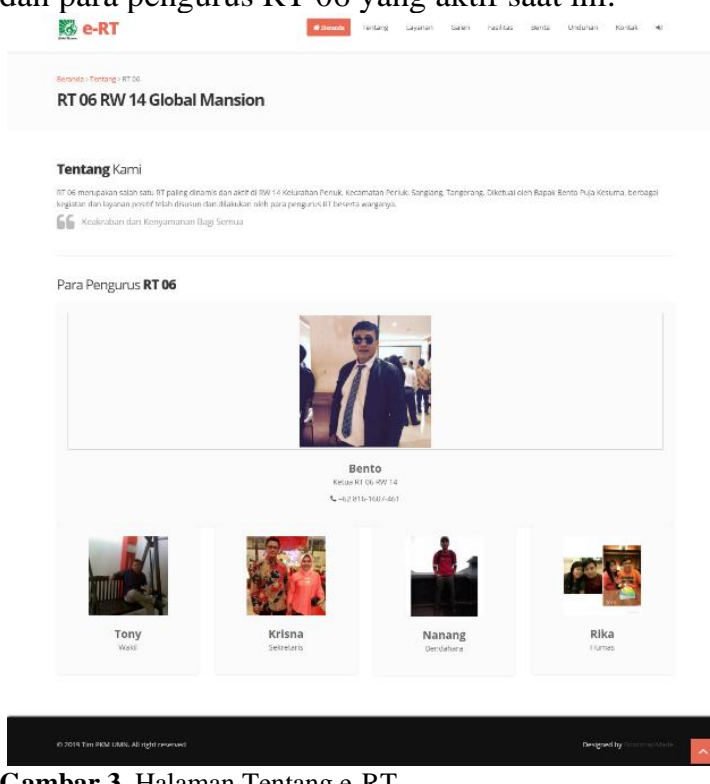

Informasi umum dan layanan pengurus RT 06 ditampilkan di halaman Layanan sebagaimana yang ditunjukkan oleh Gambar 4. Layanan Umum berisikan informasi prosedur yang dapat dilakukan warga untuk mendapatkan layanan dari pengurus RT 06 dengan lebih mudah dan cepat, sementara Informasi Umum berisikan segala informasi yang dapat dan perlu diketahui oleh warga, seperti tata tertib warga, dan sebagainya.
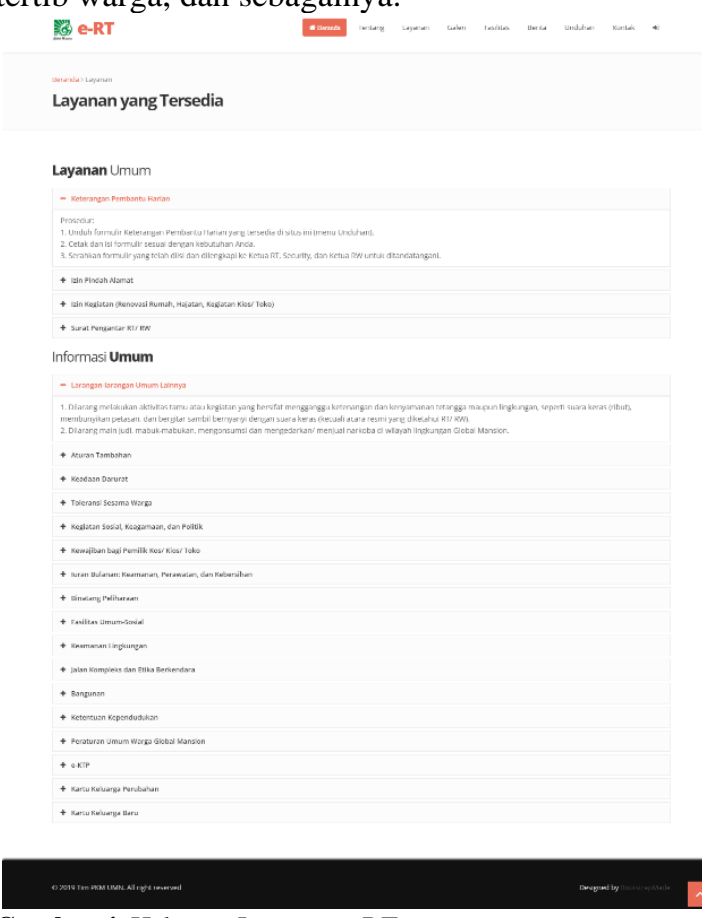

Gambar 4. Halaman Layanan e-RT
Gambar 5 memperlihatkan halaman Galeri e-RT yang menyajikan photo-photo kegiatan yang dilakukan oleh pengurus maupun warga RT 06. Setiap photo kegiatan dapat diperbesar dan diunduh oleh pengunjung e-RT.
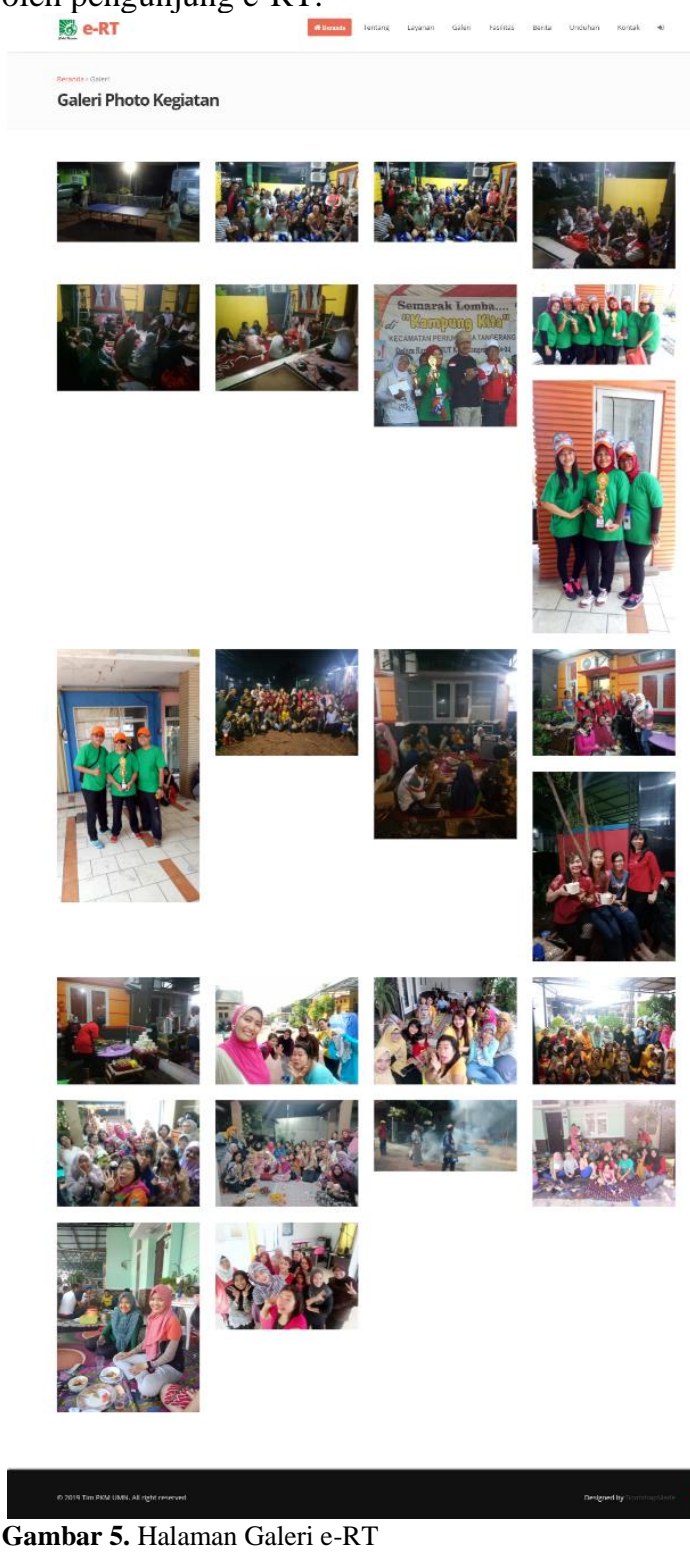

Fasilitas-fasilitas yang ada dan disediakan baik oleh warga maupun pengurus RT 06 dapat dilihat pada halaman Fasilitas, seperti yang ditunjukkan pada Gambar 6. Sementara Gambar 7 menampilkan halaman Berita yang menyajikan berita dan pengumuman dari pengurus RT yang bisa dilihat dan diunduh langsung oleh pengunjung aplikasi e-RT. 

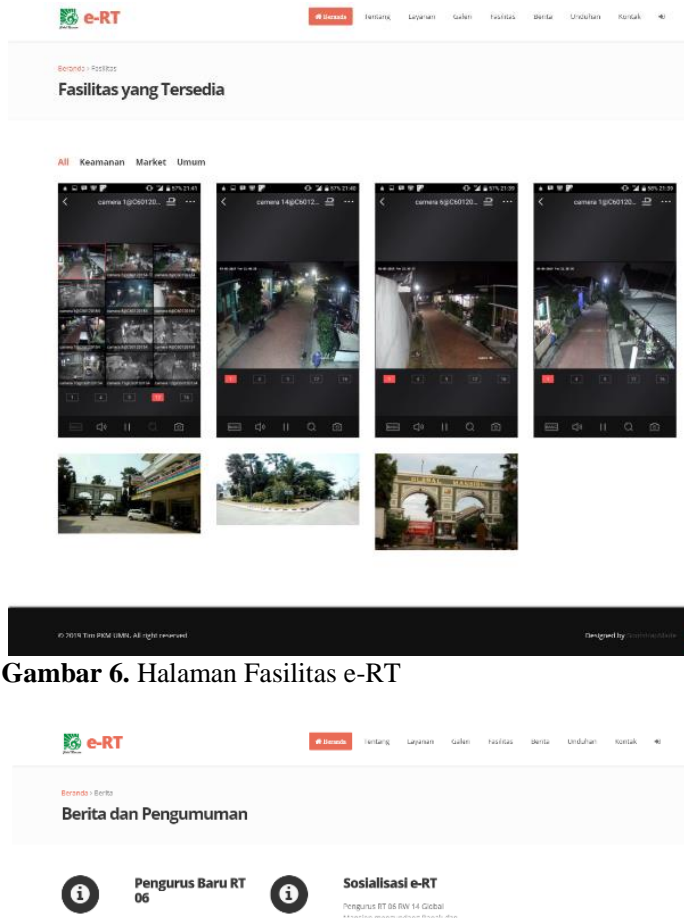

Gambar 7. Halaman Berita e-RT

Pada Gambar 8 disajikan halaman Unduhan yang berisi dokumen-dokumen yang bisa diunduh oleh pengunjung aplikasi e-RT. Umumnya dokumen yang diberikan di sini merupakan dokumen yang bisa digunakan dan diisi oleh warga secara langsung dan diharapkan dapat memudahkan proses pengurusan izin maupun kebutuhan keterangan oleh warga dari pengurus RT.
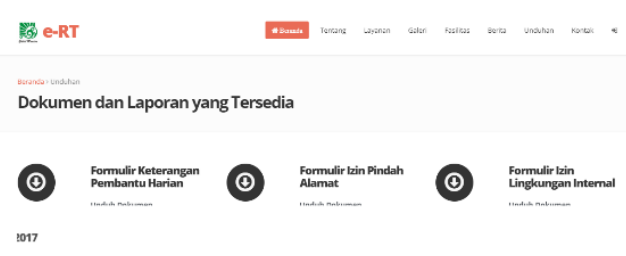

Gambar 8. Halaman Unduhan e-RT

Gambar 9 menyajikan tampilan halaman Kontak di aplikasi e-RT. Selain informasi nomornomor penting di lingkungan warga RT 06, juga terdapat informasi nomor penting terkait lainnya yang dapat dihubungi langsung bila aplikasi e-RT diakses melalui smartphone dengan cara menekan tombol telepon yang disediakan di setiap nomor kontak yang ada.
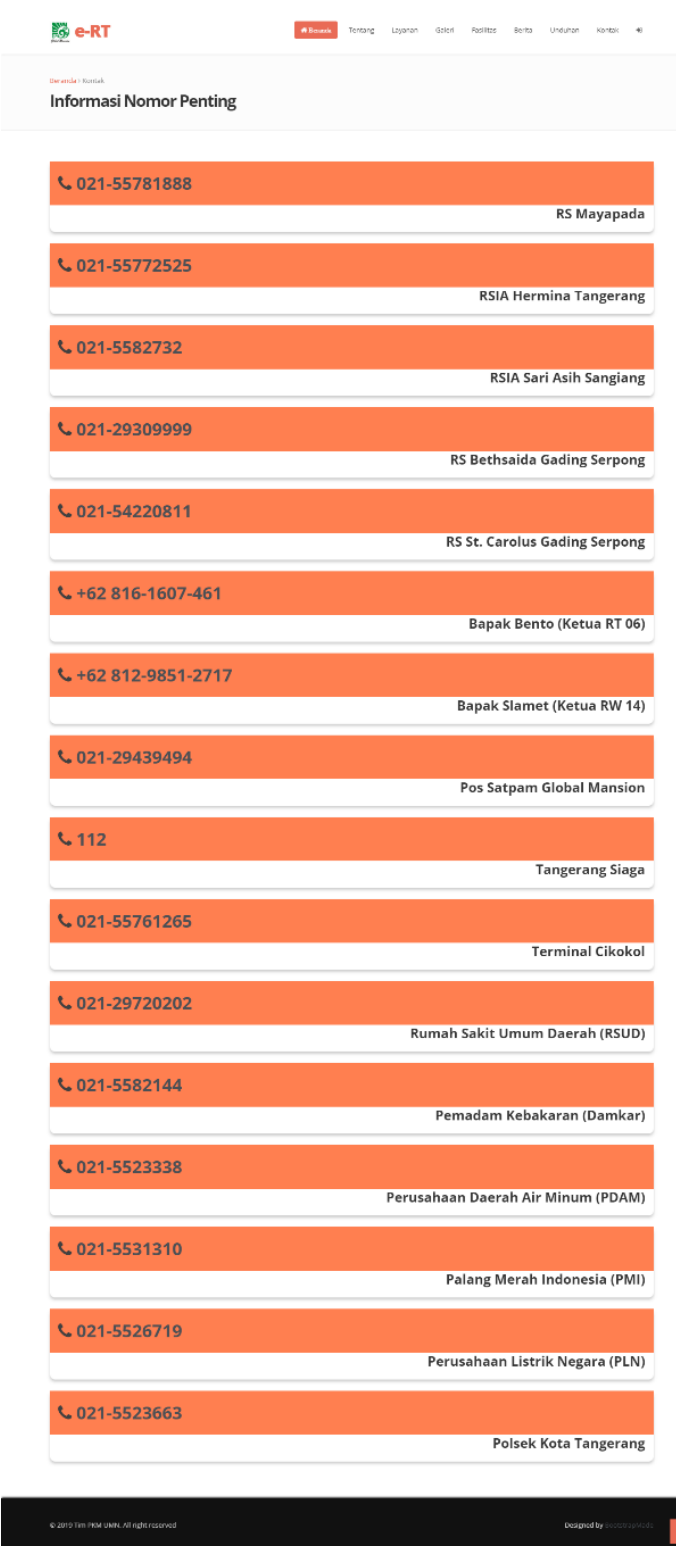

Gambar 9. Halaman Kontak e-RT

Aplikasi e-RT yang dibangun merupakan aplikasi mobile web apps (hybrid) yang dapat diakses melalui beragam perangkat yang ada, seperti notebook, tablet, smartphone, dan sebagainya. Tampilan aplikasi akan menyesuaikan resolusi layar yang digunakan oleh pengunjung aplikasi e-RT dan tetap menyajikan tampilan yang menarik.

\section{DISKUSI DAN EVALUASI}

Aplikasi e-RT yang berhasil dibangun dan diterapkan, telah disosialisasikan kepada para warga dan pengurus RT 06 pada 6 Maret 2019. Gambar 10 dan Gambar 11 memperlihatkan suasana sosialisasi aplikasi e-RT yang dilakukan dan antusiasme warga yang mengikutinya. 


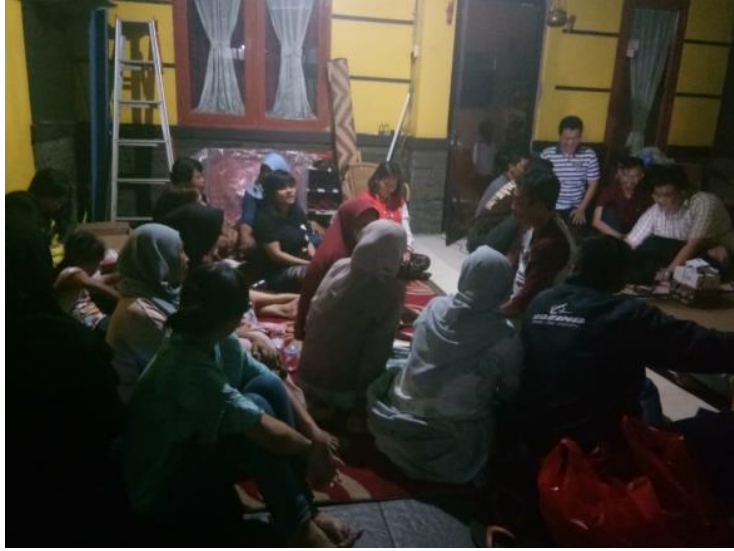

Gambar 10. Suasana Sosialisasi Aplikasi e-RT

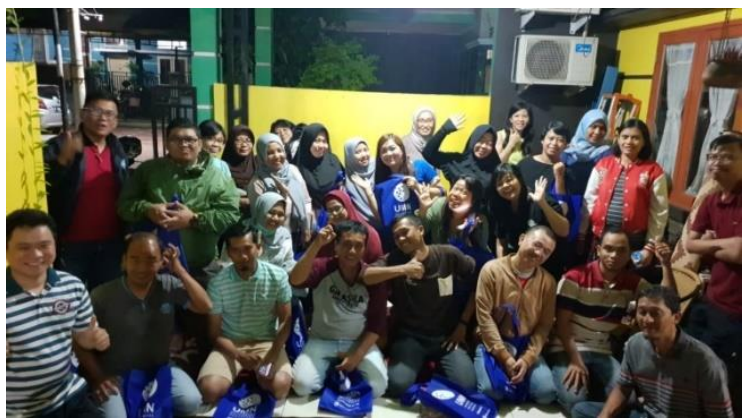

Gambar 11. Warga RT 06 Mengikuti Acara Sosialisasi e-RT

Setelah acara sosialisasi dilakukan, tim PKM juga menyebarkan angket yang bertujuan untuk mengetahui pendapat, masukan, dan penerimaan warga terkait dengan aplikasi e-RT yang telah dibangun. Angket disusun dengan menggunakan instrumen dari WEBQUAL 4.0 [11] dan terdiri atas 22 buah pertanyaan dan satu field masukan yang dapat diberikan oleh warga yang mengikuti acara sosialisasi tersebut. Total responden yang memberikan tanggapan ada 23 warga dan pengurus RT 06. Adapun hasil evaluasi yang diperoleh dari rekap data angket disajikan pada Tabel 2.

Dari hasil rekap data keseluruhan dengan menggunakan Skala Likert diperoleh nilai akhir sebesar 0,8029. Dengan demikian, tingkat kepuasan warga dan pengurus RT 06 terhadap aplikasi e-RT yang telah disosialisasikan mencapai 80,29\%. Selain itu, terdapat beberapa saran dari warga dan pengurus RT 06 yang disampaikan dalam kuesioner tersebut, seperti:

- Tampilan web cukup user friendly

- Tambahkan fitur menu jual beli

- User untuk anggota RT supaya data dapat diproteksi

- Lebih dilengkapi fiturnya sesuai dengan kebutuhan warga

- Untuk informasi lebih cepat

- Semoga dengan adanya aplikasi membuat makin mudah, lebih transparan dan aman

- Berharap dengan adanya aplikasi e-RT hubungan antar warga makin dekat dan kompak. Informasi jelas dan lengkap

- Agar bisa dibuat pin untuk masing-masing warga

- Bisa diakses untuk orang di luar RT yang bersangkutan sehingga dapat disalahgunakan

- Semoga aplikasi e-RT dapat terus melayani kebutuhan dan informasi

- Bisa dikembangkan sesuai masukan pengurus RT

- Terus menyediakan informasi dalam bentuk yang layak dalam aplikasi e-RT

- Semoga aplikasi e-RT bisa diaplikasikan ke semua RT di Global Mansion, tidak hanya di RT. 06 saja

- Memudahkan dalam pengisian data

- Sarannya semoga RT 06 semakin go public dan dikenal untuk masyarakat luas

- Sudah baik, lebih ditingkatkan lagi untuk password-nya

- Setelah adanya e-RT kita dapat pengetahuan baru. Terima Kasih

- User diberi login agar fitur rahasia untuk internal RT tidak dapat diakses secara bebas

- Disediakan kolom untuk komentar dari warga apabila ada masukan dan saran dari warga 
Tabel 2 Rekap hasil kuesioner

\begin{tabular}{|c|c|c|c|c|}
\hline Pertanyaan & SS & $\mathbf{S}$ & TS & STS \\
\hline 1. Aplikasi e-RT mudah dipelajari penggunaannya. & 8 & 15 & 0 & 0 \\
\hline 2. Interaksi dengan aplikasi e-RT jelas dan dapat dimengerti. & 4 & 19 & 0 & 0 \\
\hline 3. Navigasi dalam aplikasi e-RT mudah untuk dilakukan. & 2 & 21 & 0 & 0 \\
\hline 4. Aplikasi e-RT mudah untuk digunakan. & 3 & 20 & 0 & 0 \\
\hline 5. Aplikasi e-RT mempunyai tampilan yang atraktif. & 3 & 20 & 0 & 0 \\
\hline $\begin{array}{l}\text { 6. Aplikasi e-RT mempunyai desain yang layak / sesuai untuk tipe aplikasi lingkungan } \\
\text { perumahan. }\end{array}$ & 7 & 16 & 0 & 0 \\
\hline $\begin{array}{l}\text { 7. Aplikasi e-RT memberikan rasa kompeten ketika menggunakannya. } \\
\text { NB: Rasa kompeten yang dimaksudkan adalah tidak membuat bingung dan rasa } \\
\text { percaya diri dalam penggunaan }\end{array}$ & 3 & 19 & 1 & 0 \\
\hline 8. Aplikasi e-RT memberikan pengalaman yang baik dan positif & 8 & 15 & 0 & 0 \\
\hline 9. Aplikasi e-RT menyediakan informasi yang akurat. & 6 & 17 & 0 & 0 \\
\hline 10. Aplikasi e-RT menyediakan informasi yang terpercaya. & 5 & 18 & 0 & 0 \\
\hline 11. Aplikasi e-RT menyediakan informasi yang tepat waktu. & 7 & 15 & 1 & 0 \\
\hline 12. Aplikasi e-RT menyediakan informasi yang relevan. & 6 & 17 & 0 & 0 \\
\hline 13. Aplikasi e-RT menyediakan informasi yang mudah dipahami. & 8 & 15 & 0 & 0 \\
\hline 14. Aplikasi e-RT menyediakan detail informasi yang tepat sasaran. & 5 & 15 & 3 & 0 \\
\hline 15. Aplikasi e-RT menyediakan informasi dalam bentuk yang layak dan sesuai. & 5 & 18 & 0 & 0 \\
\hline 16. Aplikasi e-RT mempunyai reputasi yang bagus. & 5 & 17 & 1 & 0 \\
\hline 17. Transaksi data dalam aplikasi e-RT dirasa aman. & 4 & 15 & 3 & 1 \\
\hline 18. Informasi pribadi pengguna dalam Aplikasi e-RT dirasa aman. & 3 & 15 & 4 & 1 \\
\hline $\begin{array}{l}\text { 19. Aplikasi e-RT membuat pengguna merasakan personalisasi (menyediakan info/opsi } \\
\text { sesuai kebutuhan pribadi) dalam Aplikasi e-RT. }\end{array}$ & 7 & 14 & 2 & 0 \\
\hline $\begin{array}{l}\text { 20. Aplikasi e-RT membuat pengguna dapat menyampaikan kebutuhan komunitas dalam } \\
\text { Aplikasi e-RT. }\end{array}$ & 5 & 18 & 0 & 0 \\
\hline 21. Aplikasi e-RT memudahkan pengguna dalam berkomunikasi di lingkungan RT. & 5 & 18 & 0 & 0 \\
\hline $\begin{array}{l}\text { 22. Saya yakin dan percaya Aplikasi e-RT dapat melayani kebutuhan sesuai dengan yang } \\
\text { dijanjikan dan ditujukan. }\end{array}$ & 17 & 6 & 0 & 0 \\
\hline TOTAL & 126 & 363 & 15 & 2 \\
\hline
\end{tabular}

\section{KESIMPULAN}

Program Pengabdian kepada Masyarakat (PKM) UMN yang bertujuan untuk merancangbangun aplikasi e-RT dan menerapkannya pada mitra di RT 06 Kelurahan Periuk Kota Tangerang yang terletak di Perumahan Global Mansion telah berhasil dilaksanakan. Aplikasi e-RT telah dipublikasikan secara daring dan dapat diakses secara langsung melalui http://ertglobalmansion.com/

Dari hasil pelaksanaan program PKM dan evaluasi yang telah dilakukan, beberapa saran yang dapat dipertimbangkan dalam kegiatan PKM berikutnya, antara lain:

1. Fitur-fitur aplikasi e-RT dapat dikembangkan lebih lanjut, terutama untuk manajemen data kependudukan warga dan hak akses warga di aplikasi e-RT.

2. Aplikasi e-RT dapat diterapkan pada lingkungan RT tetangga yang terletak di Perumahan Global Mansion dengan seizin Ketua RW setempat.

3. Integrasi aplikasi e-RT pada aplikasi eGovernment [12].

\section{UCAPAN TERIMA KASIH}

Penulis dan tim pengusul kegiatan PKM mengucapkan terima kasih atas dukungan dana dan fasilitas yang diberikan oleh LPPM Universitas Multimedia Nusantara dalam pelaksanaan kegiatan ini.

\section{DAFTAR PUSTAKA}

[1] Lembaran Daerah Kota Tangerang, Peraturan Daerah Kota Tangerang Nomor 3 Tahun 2011 Tentang Rukun Tetangga Dan Rukun Warga (Indonesia, 2011).

[2] Achmad Subhan, "Analisis Pemberdayaan RT/RW Dan Kinerja Kelurahan Terhadap Kepuasan Pelayanan Masyarakat (Studi Kasus 6 Kelurahan Dalam Kecamatan Cengkareng Jakarta)" (Universitas Esa Unggul, 2013), https://digilib.esaunggul.ac.id/public/UEU-

Master-2580-Tesis Kepuasan Pelayanan Masyarakat.pdf.

[3] Nany Yuliastuti, Joesron Alie Syahbana, and Sugiono Soetomo, "The Role of Community Institutions 'Rukun Tetangga' in Social Housing, Indonesia," International Journal of Humanities and Social Science 5, no. 10(1) (2015): 44-52.

[4] Badan Pusat Statistik Kota Tangerang, "Jumlah Kelurahan, Rukun Warga, Dan Rukun Tetangga Di Kota Tangerang," BPS, last modified 2018, https://tangerangkota.bps.go.id/linkTableDinamis /view/id/15.

[5] Nor Eeda Haji Ali, "Pembangunan Komuniti Di Dalam Perlaksanaan Konsep Bandar Selamat, Kajian Kes: Bukit Jelutong, Seksyen U8, Shah Alam, Selangor Darul Ehsan" (Universiti Teknologi Malaysia, 2006).

[6] Merwy Rande Layuk, "Studi Tentang Kepemimpinan Ketua RT Di Desa Sebuntal 
Kecamatan Marangkayu Kabupaten Kutai Kartanegara," eJournal Ilmu Pemerintahan 1, no. 1 (2013): 165-178.

[7] Hamidah Abu Bakar, "Kepimpinan Rukun Tetangga: Satu Kajian Kes Di Kawasan Rukun Tetangga Kampung Malaysia Raya, Cheras, Kuala Lumpur" (Universiti Sains Malaysi, 2014).

[8] Bagus Mulyawan, Dedi Trisnawarman, and Zyad Rusdi, "Sistem Informasi Administrasi Kependudukan RT/RW Studi Kasus: RW 24 Kel. Bojong Nangka," in Seminar Nasional Hasil Penerapan Penelitian Dan Pengabdian Masyarakat (SNHP3M), 2014, 1-10.

[9] Muh. Nasrudin, "Sistem SMS Gateway Berbasis Web Pada Rukun Warga 01 Pedurungan Tengah Semarang" (Universitas Dian Nuswantoro, 2013), http://eprints.dinus.ac.id/12045/1/jurnal_12114.p df.
[10] Seng Hansun, Marcel Bonar Kristanda, and Muh. Salehuddin, "Rancang Bangun Aplikasi E-RT Di Kelurahan Periuk Kota Tangerang," in PKM-CSR (Lombok, 2018), 132-142, https://prosidingpkmcsr.org/index.php/pkmcsr/article/view/139/2 3.

[11] Josua Tarigan, "User Satisfaction Using Webqual Instrument: A Research on Stock Exchange of Thailand (SET)," Jurnal Akuntansi dan Keuangan 10, no. 1 (2009): 24-47, http://jurnalakuntansi.petra.ac.id/index.php/aku/a rticle/view/17001.

[12] Winarno and $\mathrm{Ni}$ Made Satvika Iswari, "Implementasi Sistem Perizinan Online (Sipinter) Dinas Penanaman Modal Dan Perizinan Terpadu Satu Pintu Kabupaten Tangerang," in PKM-CSR (Lombok, 2018), 1-10, https://prosidingpkmcsr.org/index.php/pkmcsr/article/view/43/16. 